Ophthalmologica

\title{
Question and Answer Session with Dr. Terrence P. O'Brien
}

\section{Tokyo}

Chairman: Dr. Masahiko Usui

(Tokyo Medical Univ.)

Dr. Usui: Thank you very much for your very interesting lecture. Does anybody in the audience have a question?

Dr. Sugita: Thank you for your wonderful lecture. My question is about astigmatism and light-adjustable lenses. Is it possible for us to correct astigmatism with LALs?
Dr. O'Brien: Yes, that is an excellent question. It is possible to use this technology to also correct astigmatism. There is work being done with Calhoun Vision in California with prototypes that will allow the correction of astigmatism as well. So, I think this is a technology that has many potential applications, not just in myopia and hyperopia per se, but in astigmatism and multifocality, and even wavefront correction to reduce aberrations.

Dr. Usui: Thank you very much.

\footnotetext{
KARGER

(C) 2003 S. Karger AG, Basel

Fax +4161306 1234 E-Mail karger@karger.ch 0030-3755/03/2177-0042\$19.50/0

www.karger.com

Accessible online at: www. karger.com/oph
} 